\title{
Reference Unit-based Estimates of Winterfat Browse Weights
}

\author{
DIEGO R. CABRAL AND NEIL E. WEST
}

\begin{abstract}
Precise and accurate plant weight data are important to range managers, but difficult and expensive to obtain. Indirect and nondestructive estimates are especially desirable where vegetation is sparse and slow-growing on permanent plots. A new indirect, nondestructive approach developed in Australia, the reference unit method, was quantitatively related to clipped weights of winterfat (Ceratoides lanata) browse in Curlew Valley, Utah. The reference unit method was quite precise, accurate, and efficient in predicting browse weights even though size and form of the shrubs differed greatly. The only major disadvantage was mental fatigue created by the requirement of greater sustained concentration.
\end{abstract}

Plant weight or phytomass is a variable most range managers would choose to estimate because it relates more directly to forage availability, and thus animal carrying capacity, than alternatives such as cover, density, or frequency (West 1983). However, phytomass data have not been gathered as often as desired because of notoriously high variation from small samples and the great cost and tedium in obtaining statistically adequate sample numbers via clipping approaches. These difficulties encouraged the development of numerous double sampling estimation techniques (Reese et al. 1979, Ahmed et al. 1983). These, however, require relatively large samples from clipped plots for validation and thus are expensive to do.

Australian range scientists have for several decades used a double sampling approach that combines some of the advantages of visual estimation with the curve-fitting of the newer quantitative techniques (Andrew et al. 1979). Relatively few plants have to be sacrificed to establish the quantitative relationships and these can be harvested outside permanent plots. The worker can define whatever portion of aboveground phytomass he chooses. Andrew et al. (1981) reported a very favorable comparison of the accuracy, precision and efficiency of this approach against dimensional and capacitance methods. Since only data from large, unbrowsed Australian chenopod shrubs had been presented, we thought it worthwhile to test the reference unit approach on a smaller American half-shrub under different historic levels of herbivory.

\footnotetext{
Authors are station leader, Instituto Nacional de Technologia Agropecuaria, San Rafael, Mendoza 5600, Argentina, and professor, Department of Range Science and the Ecology Center, Utah State University, Logan, Utah 84322.

This research was supported by a US Agency for International Development fellowship to the senior author.

Manuscript accepted 3 July 1985.
}

\section{Study Area}

The study area in which we chose to make this comparison was in pure winterfat [Ceratoides lanata (Moq.) J.T. Howell] communities located in Curlew Valley, Utah $\left(41^{\circ}, 52^{\prime} \mathrm{N}, 113^{\circ} 5^{\prime} \mathrm{W}, 1,350 \mathrm{~m}\right.$ elev.) Bjerregaard et al. (1984) give details of the soils here. Details of the climate of this study area can be found in Caldwell et al. (1977) and West and Gasto (1978). The mean annual temperature is $7.1^{\circ} \mathrm{C}$; yet during summer months, average daily temperatures are high (up to $32^{\circ} \mathrm{C}$ ). Average total annual precipitation is 244 $\mathrm{mm}$ with most of the precipitation coming during the winter and early spring. The precipitation for the 12 months prior to our investigation was $171 \%$ of the long-term average (Cabral 1983).

In order to test methods under differing densities and forms of the shrubs due to grazing, we selected for sampling 3 portions of the winterfat community type that had been bounded by different kinds and ages of fencing, and thus differing grazing histories. These differences are detailed in Cabral (1983).

\section{Methods}

A visually homogeneous $3 \times 50 \mathrm{~m}$ macroplot was chosen in each of the $\mathbf{3}$ sample areas. Care was taken to choose as pure a stand of Ceratoides as possible and thus simplify the testing of the method to predict browse weights. Plots were also located so as to avoid patches of bare ground around ant (Pogonomyrmex sp.) hills and badger (Taxidea taxus) mounds and thus not confound the issue with associated increases in shrub growth around such bared spots (Wight and Nichols 1968). The plots were also distant from invading taller shrubs so as to avoid possible influences of snow shadows (West and Caldwell 1983).

The macroplots were divided into 150 microplots each $1 \times 1 \mathrm{~m}$ in size. Previous work (West and Baasher 1968) had shown that $1-\mathrm{m}^{2}$ plots were more than adequate to estimate shrub densities. The proper plot size was unknown for phytomass data. The nested sampling design allowed for aggregation of data into larger plots of 3,9 , and $15 \mathrm{~m}^{2}$, if necessary. Graphical plots of running mean densities and phytomass were used to select appropriate plot size and numbers (Mueller-Dombois and Ellenberg 1974).

Densities of shrubs with more than half their root crown within each plot were estimated. Shrub cover and volume were estimated for all these micro-plots via dimensional approaches detailed in Cabral (1983). Means and standard errors derived from these data, along with other descriptors of vegetation differences between 
Table 1. Selected vegetational characteristics of three samples areas. Means of the variable are followed by the standard errors of the mean within parentheses.

\begin{tabular}{|c|c|c|c|c|c|c|c|}
\hline \multirow[b]{3}{*}{ Cover $(\%)$} & \multirow{2}{*}{$\begin{array}{c}\text { Numbers of } \\
\text { plots per area }\end{array}$} & \multicolumn{6}{|c|}{ Sampled Area } \\
\hline & & \multicolumn{2}{|c|}{ Rabbit Free } & \multicolumn{2}{|c|}{ Livestock Free } & \multicolumn{2}{|c|}{ Bureau of Land Mgt. } \\
\hline & 150 & 15.6 & $(3.59)$ & 8.3 & $(2.33)$ & 8.4 & (2.95) \\
\hline Mean Plant Cover $\left(\mathrm{cm}^{2}\right)$ & 150 & 143.1 & $(22.7)$ & 78.1 & $(12.5)$ & 69.2 & $(17.2)$ \\
\hline Mean Plant Volume $\left(\mathrm{cm}^{3}\right)$ & 150 & 1084.9 & (176.9) & 461.1 & $(127.8)$ & 336.8 & $(78.4)$ \\
\hline Mean Plant Density $\left(\# / \mathrm{m}^{2}\right)$ & 150 & 10.9 & $(0.4)$ & 10.7 & $(0.5)$ & 12.1 & $(0.5)$ \\
\hline Mean Plant Weight (g) & $3-4$ & 9.3 & $(1.7)$ & 5.4 & $(1.0)$ & 3.4 & $(0.4)$ \\
\hline Weight/Volume $\left(\mathrm{g} / \mathrm{cm}^{3}\right)$ & $3-4$ & 0.008 & $(0.0018)$ & 0.011 & $(0.0013)$ & 0.010 & $(0.0014)$ \\
\hline
\end{tabular}

Table 2. Numerical values of components of regression lines used to adjust phytomass estimations. $R F=$ rabbit free, $L F=$ livestock free. $B L M=$ open to both rabbit and livestock use.

\begin{tabular}{|c|c|c|c|c|c|c|c|c|}
\hline Area sampled & Reference unit \# & $\begin{array}{l}\text { \# plants } \\
\text { harvested }\end{array}$ & a & b & $r^{2}$ & $\mathrm{CV}^{\prime}$ & $\begin{array}{c}y=b x \\
b\end{array}$ & $\mathrm{CV}^{2}$ \\
\hline RF & 1 & 31 & 0.518 & 0.874 & 91.4 & 63.3 & 0.90 & 67.8 \\
\hline LF & 2 & 23 & 2.34 & 0.933 & 92.0 & 58.1 & 1.11 & 67.7 \\
\hline BLM & 3 & 41 & 0.833 & 0.861 & 97.9 & 60.7 & 0.91 & 67.6 \\
\hline RF & 4 & 38 & -1.29 & 0.864 & 99.3 & 63.2 & 0.83 & 67.8 \\
\hline LF & 5 & 29 & 1.89 & 0.86 & 95.5 & 53.5 & 1.00 & 67.7 \\
\hline BLM & 6 & 37 & 0.180 & 1.44 & 89.2 & 51.8 & 1.43 & 64.2 \\
\hline $\mathbf{R F}$ & 7 & 40 & 0.74 & 1.05 & 88.3 & 69.2 & 1.23 & 76.5 \\
\hline LF & 8 & 27 & 0.024 & 1.60 & 88.9 & 61.2 & 1.60 & 67.3 \\
\hline BLM & 9 & 42 & 1.45 & 1.45 & 83.9 & 56.6 & 1.75 & 64.7 \\
\hline LF & 10 & 27 & 0.75 & 0.95 & 91.6 & 62.8 & 0.73 & 68.9 \\
\hline
\end{tabular}

$\mathrm{ICV}=$ coefficient of variation of a set of clipping weights used to obtain the model $y=a+b x$.

${ }^{2} \mathrm{CV}=$ coefficient of variation after adjusting regression line through the origin.

Table 3. Mean live phytomass (oven dry weight of "live" growth = browse) per plant estimated via the reference unit method compared with values derived directly via clipping ands stripping of "live" growth. (To obtain $\mathrm{g} / \mathrm{m}^{2}$, multiply means by densities from Table 1 ).

\begin{tabular}{|c|c|c|c|c|c|c|c|}
\hline \multirow[b]{3}{*}{ Area } & \multirow{3}{*}{$\begin{array}{c}\text { Sample size } \\
\mathrm{n}\end{array}$} & \multicolumn{2}{|c|}{ Plant Reference Unit } & \multirow[b]{3}{*}{$t$} & \multirow{3}{*}{$\begin{array}{l}\text { Relative } \\
\text { Differencel }\end{array}$} & \multirow{2}{*}{\multicolumn{2}{|c|}{ Clipped and Stripped }} \\
\hline & & \multicolumn{2}{|c|}{ Estimated } & & & & \\
\hline & & Mean & St. Dev. & & & Mean & St. Dev. \\
\hline RF & 109 & 9.0 & 9.91 & 0.09 & -0.013 & 9.12 & 10.25 \\
\hline LF & 106 & 5.40 & 2.91 & 1.0 & -0.082 & 5.88 & 4.95 \\
\hline BLM & 120 & 3.58 & 2.68 & 0.1 & +0.026 & 3.49 & 2.75 \\
\hline
\end{tabular}

'Relative differences $=$ estimated - clipped $/$ clipped mean plant weights.

plots, are presented in Table 1 .

Ten $1-\mathrm{m}^{2}$ microplots, divided among 3 areas (Table 2), were randomly selected for comparison of reference unit based and direct harvest based estimates of browsed weights. The results of the direct harvest were considered the "true," actual or control values. A shrub branch (reference unit) of approximately $30-100 \%$ of the total aboveground weight of an average shrub was clipped close by the outer perimeter of the macroplots. The live tissue of each shrub within the plot was then ocularly estimated to the nearest $1 \%$ of its relative weight compared to the reference unit.

One-third of the microplots in each area were sampled in sequence before second and third rounds of the areas were completed. This was done so as to minimize the possibility that there was any growth of plants during the intervening period.

All field sampling was done during the month of August 1982, after all aboveground growth for the season had occurred and the majority of the ephemeral leaves had been lost (West and Gasto 1978). There is thus little possibility of growth having occurred within the sampling period.

Foliage wilting that occurs with hand-held samples during summer may introduce bias, thus reference units were replaced regularlv and sampling took place onlv during short periods in early morning and late afternoon. Sampling during mid-day hours was avoided to minimize wilting effects on the reference unit.

Following the estimation of reference units, every shrub with more than one-half of its root crown within the plot was cut at ground level, labelled, individually bagged and oven-dried at $75^{\circ} \mathrm{C}$ for 72 hours. What had been live tissues (mainly leaves and twigs) were separated in the lab from woody and presumed dead and nonbrowse portions of the 335 plants included in the total sample.

Least squares linear regression fits of the relationship of estimated $(y)$ to actual weights $(x)$ were calculated using the formula:

$$
y=a+b x
$$

where both unconstrained values are allowed to emerge and where $a=0$; that is, a zero intercept was forced. The latter was done because negative weight estimates make no biological sense.

The assumption of homogeneity of the variances between the 3 areas and normality of density and phytomass data were checked by the Bartlett and Chi-square tests, respectively.

\section{Results and Discussion}

The anticipated differences in mean plant density, average can- 
opy volume, and weight, among the 3 areas were confirmed (Table 1). Although plant densities were quite similar, the BLM area had the most plants; but they were much smaller, as reflected in lower average volume, cover, and weight, on both a per plant and per unit area basis (Table 1). Mean plant volume for the RF exclosure was more than 3 times larger than the mean plant volume for the BLM area (Table 1). Mean plant weight was almost 3 times as great on the RF compared to the BLM area. Intermediate values for most variables were found in the LF area (Table 1).

Variance smoothed out after 22 plots had been included in the calculations of running mean density. A total of $101-\mathrm{m}^{2}$ plots yielded smooth running means of either clipped or reference unitbased estimates of phytomass.

Log-transformed values of individual live plant phytomass were quite close to normal and variance in log-transformed weights of plot totals were homogeneous among sample areas (Cabral 1983).

The reference unit method took marginally less time [field time 0.6 (0.2 standard error of mean) minutes per plant] than clipping [field time 0.7 (0.1 standard error of mean) min.]. But, to this must be added the greater total time to strip live growth from the plants on an entire plot as contrasted to the few plants needed as reference units. It took a mean of $2.4 \mathrm{~min}$ ( 0.2 standard error of mean) to separate the live portions from a shrub.

We noted some tendency of the reference unit method to overestimate the weight of smaller plants; however, the high $r^{2}$ values in Table 2 indicate how consistent the estimates were, even without being forced through the origin.

Use of $r^{2}$ is not legitimate in the case of regressions forced through the origin (Ahmed et al. 1983). Accordingly, coefficients of variation are required to compare the reliability of the 2 forms of the regression equation. As expected, variation was always somewhat higher when the line is forced through the origin (Table 2). The increase is, however, not excessive and avoidance of predicting negative phytomass values for small plants is biologically more rational.

Estimates of the mean browse weight per plant using the reference unit and clipping methods were compared (Table 3 ). No significant differences $(\alpha=0.05)$ between mean browse weights per plant obtained by clipping or reference unit estimates were noted within areas. This was presumably because quite precise and accurate phytomass estimates were obtained from the reference unit method (Table 3). We also noted only slight differences in the magnitude of the relative differences in plots with differing grazing histories (Table 3 ). Thus, with respect to precision, accuracy and efficiency, the reference unit method was very acceptable. The only major shortcoming is the mental fatigue which can occur after several hours of making reference unit estimates. We have found in subsequent use of this method that the wilting phenomenon can be overcome by wrapping the base of the reference unit with wet paper surrounded by polyethylene wrap. This allows readings to be made throughout the day without wilting or need to change reference units.

By use of hand-held scales, a field worker could quickly validate the accuracy and precision of his estimates of fresh weights. If a reasonably constant conversion factor for wet to dry weight exists (Sharif and West 1968), total phytomass could be rather easily and reliably estimated on rangelands dominated by one or a few species. One, of course could also use this method to estimate the browse on any selected portion of a key species in a mixed stand. If no confidence limits are required, and linear fits occur, or are forced through zero, then raw data can be accumulated in the field and converted to forage weight directly.

\section{Literature Cited}

Ahmed, J., C.D. Bonham, and W.A. Laycock. 1983. Comparison of techniques for adjusting biomass estimates by double sampling. J. Range Manage. 36:217-221.

Andrew, M.H., I.R. Noble, and R.T. Lange. 1979. A non-destructive method for estimating the weights of forage on shrubs. Austr. Rangeland J. 1:225-231.

Andrew, M.H., I.R. Noble, R.T. Lange, and A.W. Johnson. 1981. The measurement of shrub forage weight: Three methods compared. Austr. Rangeland J. 3:74-82.

Bjerregaard, R.S., N.E. West, M.M. Caldwell, and H.F. Mayland. 1984. Standing crops and dynamics of phytomass and minerals in two salt desert shrub communities. Great Basin Natur. 44:327-337.

Cabral, D.R. 1983. Plant weight-density relationships on salt desert shrublands with differing range condition. M.S. thesis, Utah State Univ., Logan.

Caldwell, M.M., R.S. White, R.T. Moore, and L.B. Camp. 1977. Carbon balance, productivity, and water use of cold-winter desert shrub communities dominated by $C_{3}$ and $C_{4}$ species. Oecologia (Berlin) 29:275-300.

Mueller-Dombois, D., and H. Ellenberg. 1974. Aims and methods of vegetation ecology. John Wiley and Sons, New York.

Reese, G.A., R.L. Bayn, and N.E. West. 1979. Evaluation of doublesampling estimators of subalpine herbage production. J. Range Manage. 33:300-306.

Sharif, C.M., and N.E. West. 1968. Forage moisture variations on mountain summer range. J. Range Manage. 21:228-235.

West, N.E. 1983. Choice of vegetational variables for assessing range condition and monitoring trend. p. 636-639. In: J.T. Bell and T. Atterbury (eds.) Proc. Int. Conf. on Renewable Resource Inventories for Monitoring Changes and Trends. Oregon State Univ., Corvallis.

West, N.E., and M.M. Baasher. 1968. Determination of adequate plot size by use of mean distance between salt desert shrubs. SW Nat. 13:61-74.

West, N.E., and J. Gasto. 1978. Phenology of the aerial portions of shadscale and winterfat in Curlew Valley, Utah. J. Range Manage. 31:43-45.

West, N.E., and M.M. Caldwell. 1983. Snow as a factor in salt desert shrub vegetation patterns in Curlew Valley, Utah. Amer. Midl. Nat. 109:376-379.

Wight, J.R., and J.T. Nichols. 1968. Effects of harvester ants on production of a saltbush community. J. Range Manage. 19:68-71. 